\title{
The Effect of Pressure-Induced Mechanical Stretch on Vascular Wall Differential Gene Expression
}

\author{
M.A. Anwar J.Shalhoub C.S. Lim M.S. Gohel A.H. Davies \\ Academic Section of Vascular Surgery, Department of Surgery and Cancer, Imperial College London, \\ Charing Cross Hospital, London, UK
}

\section{Key Words}

Gene expression $\cdot$ Arteries $\cdot$ Veins $\cdot$ Stretch $\cdot$ Pressure

\begin{abstract}
High blood pressure is responsible for the modulation of blood vessel morphology and function. Arterial hypertension is considered to play a significant role in atherosclerotic ischaemic heart disease, stroke and hypertensive nephropathy, whereas high venous pressure causes varicose vein formation and chronic venous insufficiency and contributes to vein bypass graft failure. Hypertension exerts differing injurious forces on the vessel wall, namely shear stress and circumferential stretch. Morphological and molecular changes in blood vessels ascribed to elevated pressure consist of endothelial damage, neointima formation, activation of inflammatory cascades, hypertrophy, migration and phenotypic changes in vascular smooth muscle cells, as well as extracellular matrix imbalances. Differential expression of genes encoding relevant factors including vascular endothelial growth factor, endothelin-1, interleukin-6, vascular cell adhesion molecule, intercellular adhesion molecule, matrix metalloproteinase- 2 and -9 and plasminogen activator inhibitor-1 has been explored using ex vivo cellular or organ stretch models and in vivo experimental animal models. Identification of pertinent genes may unravel new thera-
\end{abstract}

peutic strategies to counter the effects of pressure-induced stretch on the vessel wall and hence minimise its notable complications.

Copyright $\odot 2012$ S. Karger AG, Basel

\section{Introduction}

Arterial hypertension is a progressive cardiovascular syndrome associated with functional and structural cardiovascular abnormalities that damage various organs including the heart, kidneys, brain and other vasculatures and lead to premature morbidity and death [1]. Similarly, venous valvular incompetence and elevation in the pressure of blood in the lower-limb superficial venous system is considered contributory to vein dilatation and tortuosity (varicose veins) [2]. Importantly, such increased venous pressure is also responsible for chronic venous insufficiency (CVI), which manifests as lipodermatosclerosis, oedema and ulceration [2].

There are three main cell types found in the main layers of the blood vessel wall, namely endothelial cells (ECs) lining the tunica intima, vascular smooth muscle cells (VSMCs) in the tunica media and fibroblasts within the adventitia. These cells have the ability to respond to various micro- and macro-environmental stimuli including 
Fig. 1. Diagram showing haemodynamic forces in a blood vessel. Distension pressure results in a radial force applied to the vessel wall, which in turn leads to elongation of the wall and alignment of the vascular cells in a direction that is perpendicular to the applied force $[38,48]$.

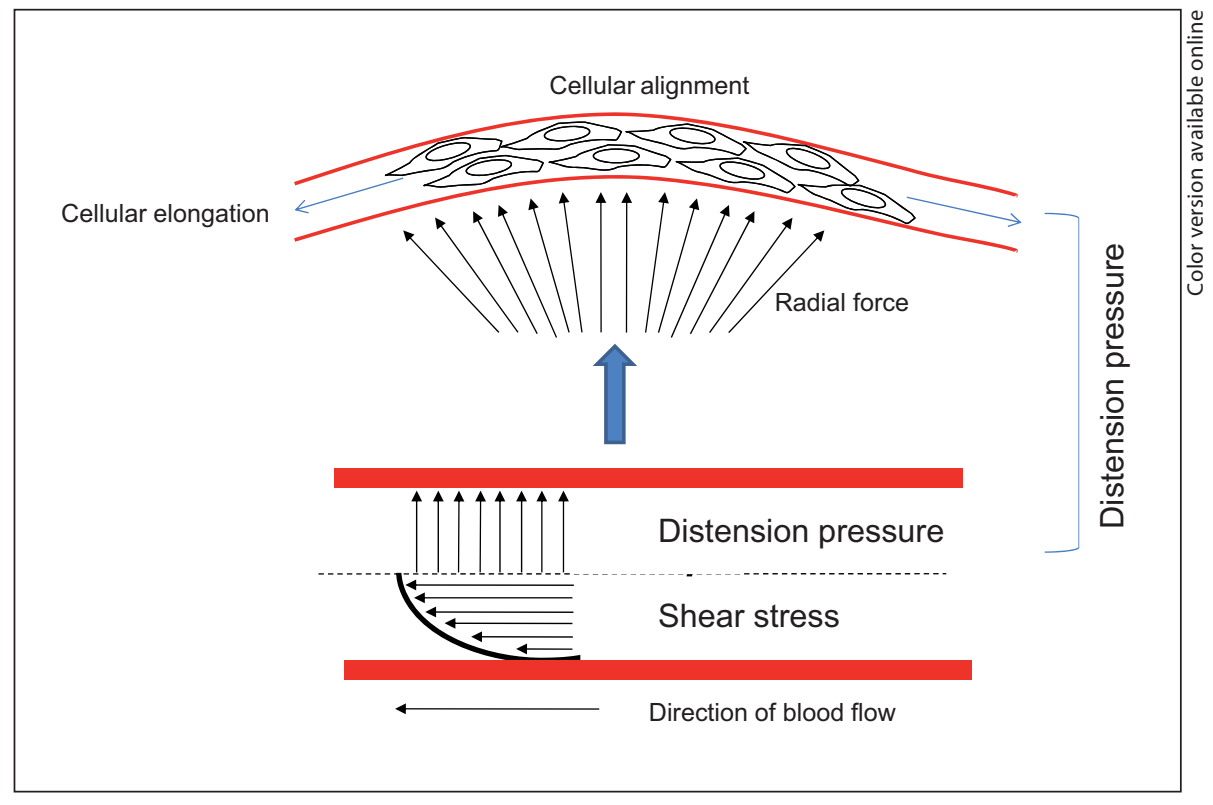

mechanical stretch. The elastic ability of large vessels allows them to accommodate significant volumes of blood under physiological conditions. However, upon exposure to high pressure, the structural and functional properties of vessels are modified to accommodate this by a process termed 'vascular remodelling'. Remodelling encompasses alterations in the migration, proliferation and apoptosis of ECs and VSMCs and synthesis and degradation of extracellular matrix (ECM) [3]. More elastic vessels, such as the aorta, attenuate the effects of hypertension initially by way of remodelling, but prolonged hypertension in these large elastic arteries and particularly in less elastic vessels (such as smaller arteries and veins) tends to alter the vessel wall shape and composition, ultimately resulting in various clinical complications. The aim of this review is to summarise current knowledge relating to changes in gene expression as a result of high intravascular pressure and the morphological changes in artery and vein walls induced by the altered expression of these genes.

\section{Methods}

A literature review of the Pubmed database was conducted using the following search string: ('gene' OR 'genes' OR 'gene expression') AND ('stretch' OR 'distension' OR 'pressure' OR ‘tension') AND ('vessel' OR 'arterial' OR 'artery' OR 'venous' OR 'veins'). The search was expanded using the 'related articles' function and article reference lists. Only English-language articles were included.

\section{Blood Pressure and Mechanical Forces}

Forces exerted by blood on the vessel wall include mechanical stretch and shear stress (fig. 1). Increased intraluminal pressure of the blood distends the vessel wall, exerting a force perpendicular to its surface. The vessel opposes this distension by applying a circumferential and longitudinal force. All the constituents of the vessel wall take part in counter-balancing the effect of blood pressure [4]. According to Laplace's law, this force per unit length of vessel wall $(\mathrm{T})$ is directly proportional to the blood pressure $(\mathrm{P})$ and wall radius ( $\mathrm{r}$ ) and inversely proportional to its thickness (h): $\mathrm{T}=\mathrm{Pr} / \mathrm{h}$.

Shear stress is applied parallel to the vessel surface and is generated due to friction of the blood against the vessel wall. The effect of shear stress is borne directly by the endothelial lining of the blood vessel [4]. Shear stress $(\tau)$ is directly proportional to the blood viscosity $(\mu)$ and the rate of flow $(\mathrm{Q}): \tau=4 \mu \mathrm{Q} / \pi \mathrm{r}^{3}$, where $\mathrm{r}=$ vessel radius.

The mechanical stretch (circumferential stress) in arteries is mainly cyclical due to pulsatile blood flow, increasing in the systolic phase of the cardiac cycle and gradually reducing during diastole. All elements of the vessel wall including all three main cell types and ECM are affected by the mechanical stretch. As a consequence, up- or downregulation of genes and their transcriptomic or proteomic products will form the basis of this review. 


\section{Morphological Effects of Mechanical Stretch on Blood Vessels}

Forces exerted by blood pressure on the arterial wall affect the vessel wall at both the cellular and molecular level. Evidence has shown that the tension generated by intraluminal pressure affects the thickness and composition of the vessel wall $[5,6]$. Mechanical stretch exerted by increased intraluminal pressure induces vascular smooth muscle hypertrophy and hyperplasia and changes in contractile and matrix proteins $[7,8]$. Localised haemodynamic stresses in arteries are considered to play a role in attracting inflammatory cells into the arterial wall [9]. These inflammatory cells produce cytokines, chemokines, oxygen free radicals and matrix metalloproteinases (MMPs), the latter leading to degradation of wall structural components including elastin and collagen. Similarly, vascular ECs and VSMCs produce MMPs [9]. A weak arterial wall, in the context of ongoing exposure to such wall stresses, is susceptible to aneurysmal dilatation.

High arterial blood pressure certainly plays a part in the pathogenesis of atherosclerosis [10]. In response to endothelial injury, a complex interaction between these activated ECs, VSMCs, platelets and leukocytes results in an inflammatory cascade [11]. This interaction also changes the vasomotor status of the blood vessels, alters the coagulation cascade and fibrinolytic system and stimulates VSMC proliferation and migration. These processes contribute to the development of an atherosclerotic lesion in the vessel intima [12]. In the regions of arterial branching, there is greater susceptibility to atherogenesis owing to the greater effect of the haemodynamic forces of shear stress [13] and mechanical stretch [14].

The venous system functions as a blood capacitance reservoir and also a channel to return the blood to the heart. As veins are exposed to lower pressure, it is logical to expect less mechanical stretch and shear stress in veins in comparison to arteries. However, this hypothesis does not consider the thinner, less muscular and more compliant nature of the vein wall. The peripheral venous system in the lower limbs is divided into superficial and deep components. Superficial veins are located outside the musculo-fascial compartments and are connected to the deep venous system by perforating veins. From the clinical perspective, the peripheral venous system is important, as failure of this system is associated with CVI. The peripheral venous system is supported by valves and muscle pumps to help pump blood centrally towards the heart and prevent retrograde flow into the legs (termed venous reflux). Failure of the valves or muscle pump leads to increased pooling of blood in the legs and high venous pressure exerting a static stretch on the vein wall. The resting standing venous pressure in a normal leg is about $80-100 \mathrm{~mm}$ Hg. During calf muscle contraction, the venous pressure normally drops to $20-30 \mathrm{~mm} \mathrm{Hg}$, followed by venous refilling. However, patients with venous reflux demonstrate a less than $50 \%$ venous pressure drop during calf contraction and a much shorter refilling time [2]. The overall increased venous pressure as a result of blood stasis may result in vein wall dilatation and the characteristic CVI dermal changes with hyperpigmentation, venous eczema, subcutaneous tissue fibrosis and ultimately ulceration $[2,15]$.

Under physiological conditions, veins do not normally develop atherosclerotic disease. However, the autologous superficial great saphenous vein is the most commonly used conduit in coronary artery bypass surgery and is also regarded as an appropriate conduit in the context of chronic and critical limb ischaemia [16-19]. Veins used as conduits for arterial reconstruction in heart and limb bypass operations are also known as 'arterialised veins', as they are subjected to relatively high arterial pressure. Arterialised veins are more likely to develop atherosclerotic disease, which may lead to vein graft failure [20]. The risk of vein graft failure is estimated to be around $50 \%$ over 10 years in coronary arterial disease and approximately $30 \%$ over 1 year for peripheral arterial disease [21-23].

\section{Functional Aspects of in vitro Stretch Experiments}

The vessel wall opposes the intraluminal stretch of blood pressure, and this resistance is manifested by changes in the vessel wall in both circumferential and longitudinal directions (fig. 1). Therefore, mechanical strain is a measure of deformation and change in the length of the cells. The percentage increase in the length of the deformed cell caused by stretch is calculated as the ratio of the circumference when stretched to the initial circumference. Human aorta undergoes an $8-10 \%$ oscillation in external diameter under physiological conditions due to expansion of its elastic fibres [24]. However, the peripheral arteries undergo an approximately $5 \%$ oscillation in diameter due to the elastin being well supported by collagen and smooth muscle cells (SMCs) in the tunica media of their walls [25]. However, when the blood pressure is high, including in hypertension, the change in the aortic diameter has been modelled in vitro as $20 \%$ [26-28]. Therefore, $20 \%$ stretch is often applied in cell culture studies to in- 
vestigate the effects of hypertension-induced stretch. For example, commercially available Flexercell FX-2000 devices are used in studies to apply an in vitro cyclical stretch on cultured vascular ECs and VSMCs on an elastic membrane. Mechanical strain to cultured cells under study is applied through a vacuum unit linked to a computer programme. Cultured cells resting on the flexible membranes are deformed by a sinusoidal negative pressure of $15 \mathrm{kPa}$ $(113 \mathrm{~mm} \mathrm{Hg})$ controlled by a computer at a frequency of $1 \mathrm{~Hz}$ (60 cycles/min) [29]. This stretching model produces a cyclical strain on cells ranging from minimal strain at the centre of the membrane to a peak value of $20 \%$ at the periphery [30].

The effects of stretch are studied in whole blood vessels in ex vivo experiments using vein or arterial organ culture models. For example, segments of blood vessels suspended in a culture medium are stretched with 0.5 - or 2 -gram weights (2-gram weight $=83 \mathrm{~mm} \mathrm{Hg}$ ) using stainless steel hooks [31]. Isolated aortic segments attached to bespoke cold perfusion circuits [32] and carotid artery segments cannulated to rods in a self-contained flow system have also been used to study the effects of stretch on the vessel wall [33]. Shunts and fistulae formed between arteries and veins have also been developed in experimental animal models to look at the effects of high arterial pressure on the vein wall $[34,35]$.

\section{Cellular Mechanosensing and Intracellular Pathways}

The cellular mechanosensitive mechanisms detecting and transmitting the effects of intraluminal stretch include cell adhesion sites, integrins, cellular junctions, tyrosine kinase receptors, ion channels and components of the lipid bilayer (fig. 2) [4, 26, 36-38]. Activation of such mechanosensors initiates multiple complex intracellular pathways which drive patterns of gene expression. These signalling pathways are numerous and often overlapping. Protein kinase C, Rho family GTPases such as Rho and Rac and activation of phosphatidylinositol-3-kinase and its downstream target Akt are involved in stretch signal transduction [27]. In addition, stretch also activates mitogen-activated phosphate kinases (MAPKs) $[39,40]$. The MAPK cascade consists of three pathways including extracellular signal-regulated kinases 1 and 2 and stressactivated protein kinases (such as c-Jun $\mathrm{N}$-terminal kinase and p38) [36, 39, 41-43]. Downstream of the MAPK cascade includes ternary complex formation with the serum response element on gene promoters and activation of transcription factors such as c-fos, c-Jun and activator protein-1, which bind to DNA transcription promoter sites [4]. Cyclical strain also affects many transcription factors such as activator protein-1, cAMP, serum response element and nuclear factor- $\kappa \mathrm{B}(\mathrm{NF} \kappa \mathrm{B})$. These transcription factors are known to be involved in the cyclicalstrain-mediated regulation of gene expression $[44,45]$. As a result of up- and downregulation of specific genes, key cellular processes such as cell proliferation, apoptosis, cell migration and the synthesis, degradation and reorganisation of the ECM may be modulated. This review underlines the effects of haemodynamic stretch on regulation of specific genes associated with particular morphological changes in the vessel wall.

\section{Effect of Stretch on Genes Affecting Growth and Apoptosis}

ECs serve various important functions including maintaining vascular haemostasis and secretion of a number of vasoactive and anti-thrombogenic mediators. VSMCs provide strength to the vascular structure. VSMCs also regulate ECM turnover and vascular tone. Under physiological conditions, there is a balance between cell proliferation and apoptosis to maintain function and prevent hyperplasia. Any stress, including mechanical stretch, may lead to cellular dysfunction and dysregulation.

Cyclical stretch affects the proliferation and apoptosis of ECs and VSMCs (for the effect on genes regulating proliferation/apoptosis and VSMC phenotype, see table 1). Studies involving both venous and arterial cultured ECs have shown an increased cell proliferation upon exposure to stretch $[46,47]$. Cultured ECs on flexible membranes subjected to cyclical strain have shown cellular elongation and perpendicular alignment to the direction of stretch (fig. 1) [48]. Application of a $20 \%$ pathological cyclical strain to human umbilical vein ECs (HUVECs) has been shown to induce a 2.5 -fold increase in activity of the $\mathrm{c}-\mathrm{Myc}$ promoter after $2 \mathrm{~h}$. Important upregulated downstream genes of c-Myc are vascular endothelial growth factor (VEGF), proliferating cell nuclear antigen and heat shock protein-60. These genes are thought to be involved in cell proliferation and matrix re-accumulation in stenotic diseases including neointima formation in vein bypass grafts [28]. Furthermore, stretch increases the sensitivity of ECs to growth factors [46].

The effects of cyclical stretch on the life cycle of VSMCs (proliferation and apoptosis) are not clear [27]. Evidence from studies applying stretch to cultured ve- 


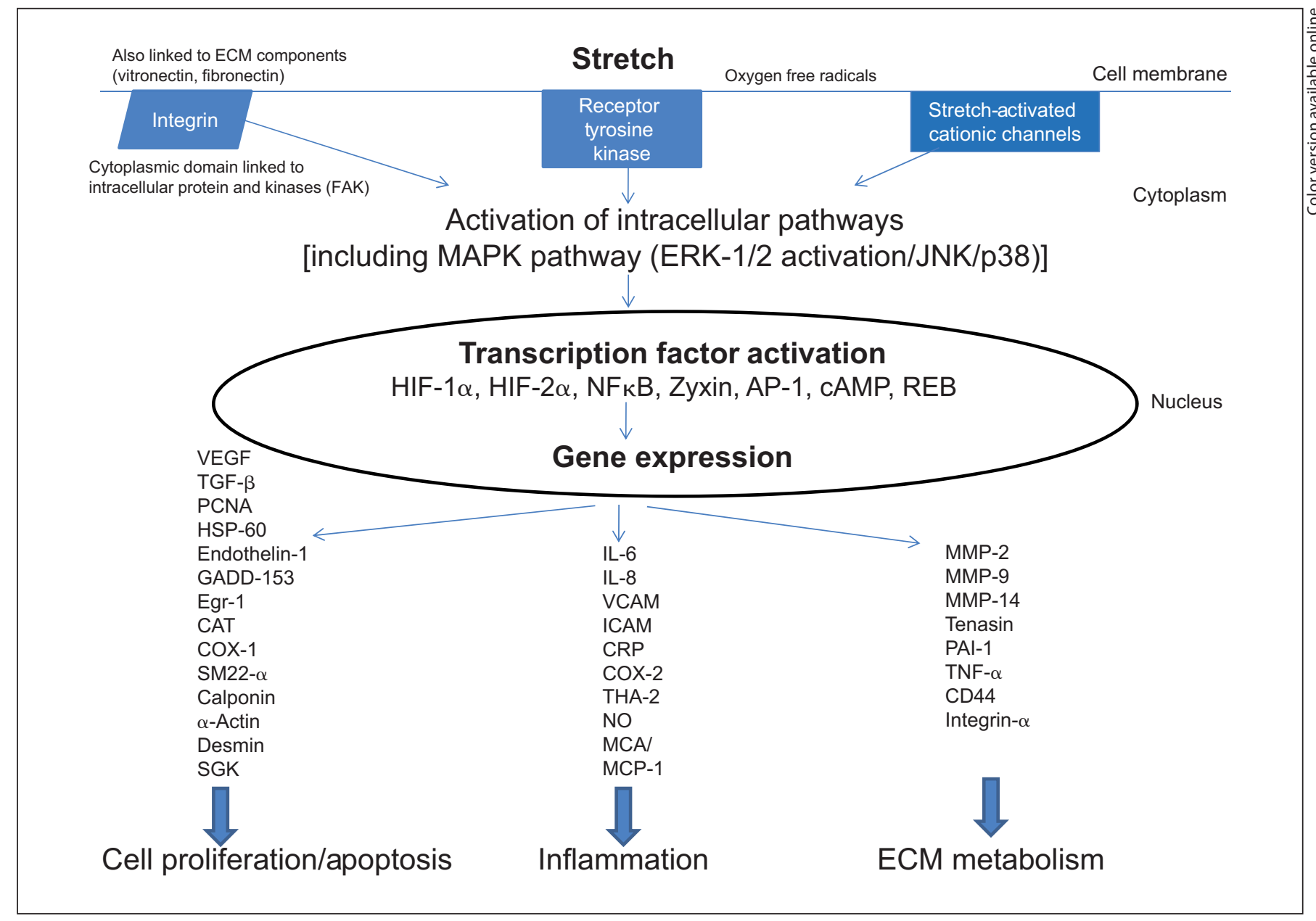

Fig. 2. Diagram summarising the effects of stretch on vascular ECs and VSMCs. AP-1 = Activator protein-1; CAT = catalase; Egr-1 = early growth response gene-1; ERK-1/2 = extracellular signal regulated kinases 1 and $2 ; \mathrm{FAK}=$ focal adhesion kinase; GADD-153 = growth arrest and DNA damage-inducible gene 153; JNK = c-Jun N-terminal kinase; HSP-60 = heat shock protein- 60 ; $\mathrm{MCA}=$ monocyte chemotactic antigen; $\mathrm{NO}=$ nitric oxide; $\mathrm{PCNA}$
= proliferating cell nuclear antigen; $\mathrm{REB}=$ response elementbinding protein; SGK = serum-glucocorticoid-induced protein kinase (a serine/threonine protein kinase); SM22- $\alpha=$ smooth muscle cells specific protein; TGF- $\beta=$ transforming growth factor- $\beta$; THA- $2=$ thromboxane synthase-A2; TNF- $\alpha=$ tumour necrosis factor- $\alpha$. nous SMCs and ECs and a vein organ cultured ex vivo model has demonstrated increased apoptosis in VSMCs [49-52] (for the details of differential genes affecting growth, see table 1). This effect may be load dependent, as seen in a study in which $25 \%$ stretch caused DNA fragmentation in VSMCs whilst 7\% stretch protected VSMCs from apoptosis [41]. Interestingly, similar degrees of stretch have been shown to result in both apoptosis and proliferation in VSMCs $[53,54]$.

On the other hand, evidence from studies of arterial cell cultures subjected to stretch has shown increased expression of hypoxia-inducible factor (HIF)- $1 \alpha$, VEGF and transforming growth factor- $\beta 1$, all favouring VSMC proliferation $[29,55]$. Following static mechanical stretch of rat skeletal muscles for 4 and 7 days, cultured capillary ECs isolated by laser capture micro-dissection were found to display increased transcription of HIF- $1 \alpha$ and $-2 \alpha$ and their DNA-binding activity [56]. HIFs are key nuclear transcriptional factors that regulate genes mediating oxygen homoeostasis $[57,58]$, including those involved in ECM metabolism (MMPs and tissue inhibitors of metalloproteinases), vascular tone, cell survival and apoptosis, glucose transportation, angiogenesis, erythropoiesis and oxygen delivery $[57,59]$. 
Table 1. Mechanical stretch induces expression of various genes in ECs and VSMCs affecting cell growth/apoptosis and phenotype

\begin{tabular}{|c|c|c|c|c|}
\hline Study & Cell type and origin & Stretch method employed & Genes regulated & Effect on the vessel wall \\
\hline $\begin{array}{l}\text { Hurley et al. } \\
2010[28]\end{array}$ & HUVECs & $\begin{array}{l}\text { cultured cells } \\
20 \% \text { cyclical stretch }\end{array}$ & $\begin{array}{l}\uparrow \mathrm{c}-\text { Myc }(2.6 \text {-fold }) \text { at } 1-2 \mathrm{~h} \\
\uparrow \mathrm{c}-\text { Myc-regulated genes: } \\
\text { VEGF }(3.5 \text {-fold at } 4 \mathrm{~h}) \\
\text { HSP-60 }(2.6 \text {-fold at } 4 \mathrm{~h}) \\
\text { PCNA }(1.75 \text {-fold at } 3 \mathrm{~h})\end{array}$ & $\begin{array}{l}\text { cell proliferation } \\
\text { ECM remodelling }\end{array}$ \\
\hline $\begin{array}{l}\text { Frye et al. } \\
2005 \text { [47] }\end{array}$ & HUVECs & $\begin{array}{l}\text { cultured cells } \\
10 \% \text { cyclical and non-cyclical } \\
\text { stretch }\end{array}$ & $\begin{array}{l}\uparrow \mathrm{CAT} \text { (catalase) with cyclical but not } \\
\text { non-cyclical stretch }\end{array}$ & cell proliferation \\
\hline $\begin{array}{l}\text { Stula et al. } \\
2000[50]\end{array}$ & HUVECs & $\begin{array}{l}\text { cultured cells } \\
10 \% \text { continuous stretch }\end{array}$ & $\begin{array}{l}\uparrow \text { early growth response }(\mathrm{Egr}-1) \text { at } 10 \\
\text { min, reached peak at } 30 \mathrm{~min}\end{array}$ & $\begin{array}{l}\text { chemotactic and mitogenic } \\
\text { effects on VSMCs }\end{array}$ \\
\hline $\begin{array}{l}\text { Zheng et al. } \\
2004[46]\end{array}$ & $\begin{array}{l}\text { RCMEs } \\
\text { HUVECs }\end{array}$ & $\begin{array}{l}\text { cultured cells } \\
15 \% \text { cyclical stretch for } 24 \mathrm{~h}\end{array}$ & $\begin{array}{l}\uparrow \text { protein expression of receptor tyrosine } \\
\text { kinases: } \\
\text { Flk } 1 \text { (both cell types) } \\
\text { Tie } 1 \text { (only in RCMEs) } \\
\text { Tie } 2 \text { (both cell types) }\end{array}$ & $\begin{array}{l}\text { increase in sensitivity of ECs } \\
\text { to growth factors }\end{array}$ \\
\hline $\begin{array}{l}\text { Cattaruzza } \\
\text { et al. } 2000 \text { [67] }\end{array}$ & $\begin{array}{l}\text { PAECs } \\
\text { rat aortic VSMCs }\end{array}$ & $\begin{array}{l}\text { cultured cells } \\
20 \% \text { cyclical stretch for } 6 \mathrm{~h}\end{array}$ & $\begin{array}{l}\uparrow \mathrm{ET}-1 \text { (8-fold) in PAECs } \\
\uparrow \mathrm{ET}-\mathrm{B} \text { receptor in rat VSMCs }\end{array}$ & $\begin{array}{l}\text { ET-1 release from ECs } \\
\text { causes vasoconstriction but } \\
\text { in response to stretch causes } \\
\text { ET-B-induced apoptosis of } \\
\text { VSMCs }\end{array}$ \\
\hline $\begin{array}{l}\text { Milkiewicz } \\
\text { et al. } 2007[56]\end{array}$ & $\begin{array}{l}\text { skeletal muscle } \\
\text { capillary endothelial } \\
\text { cells (rat) }\end{array}$ & $\begin{array}{l}10 \% \text { static stretch to skeletal } \\
\text { muscles }\end{array}$ & $\begin{array}{l}\uparrow \text { HIF- } 1 \alpha \\
\text { (3-fold on day } 4 \text { and } 4 \text {-fold on day } 7) \\
\uparrow \text { HIF- } 2 \alpha(2.5 \text {-fold on days } 4 \text { and } 7)\end{array}$ & $\begin{array}{l}\text { increase in expression of } \\
\text { HIF target gene VEGF } \\
\uparrow \text { permeability } \\
\uparrow \text { cell proliferation } \\
\uparrow \text { angiogenesis }\end{array}$ \\
\hline $\begin{array}{l}\text { Cheng et al. } \\
2010[101]\end{array}$ & venous SMCs (mice) & $\begin{array}{l}\text { cultured cells } \\
15 \% \text { cyclical stretch for } 2 \mathrm{~h}\end{array}$ & $\uparrow$ SGK (19-fold) in venous SMCs & increased proliferation \\
\hline $\begin{array}{l}\text { Feng et al. } \\
1999 \text { [61] }\end{array}$ & human aortic SMCs & $\begin{array}{l}\text { cultured cells } \\
4 \% \text { cyclical stretch for } 12 \text { or } 24 \mathrm{~h}\end{array}$ & $\begin{array}{l}\uparrow>2.5 \text {-fold: } \\
\text { COX-1 } \\
\text { tenasin } \\
\text { PAI- } 1 \\
\downarrow>2.5 \text {-fold: } \\
\text { MMP-1 } \\
\text { thrombomodulin }\end{array}$ & $\begin{array}{l}\text { reduced VSMC } \\
\text { proliferation } \\
\text { ECM remodelling }\end{array}$ \\
\hline $\begin{array}{l}\text { Cheng et al. } \\
2008[49]\end{array}$ & VSMCs (rat) & $\begin{array}{l}\text { cultured cells } \\
20 \% \text { cyclical stretch }\end{array}$ & $\uparrow$ GADD-153 (4.5-fold over $18 \mathrm{~h}$ ) & apoptosis \\
\hline $\begin{array}{l}\text { Chang et al. } \\
2003 \text { [29] }\end{array}$ & $\begin{array}{l}\text { thoracic aorta VSMCs } \\
\text { (animal) }\end{array}$ & $\begin{array}{l}\text { cultured cells } \\
20 \% \text { cyclical stretch }\end{array}$ & $\uparrow$ HIF- $1 \alpha(2.1$-fold at $4 \mathrm{~h})$ & $\begin{array}{l}\text { increase in expression of } \\
\text { HIF target gene VEGF } \\
\uparrow \text { permeability } \\
\uparrow \text { cell proliferation } \\
\uparrow \text { angiogenesis }\end{array}$ \\
\hline $\begin{array}{l}\text { Richard } \\
\text { et al. } 2007 \text { [60] }\end{array}$ & $\begin{array}{l}\text { thoracic aorta VSMCs } \\
\text { (rabbit) }\end{array}$ & $\begin{array}{l}\text { cultured cells } \\
20 \% \text { cyclical stretch }\end{array}$ & $\uparrow \mathrm{PCNA}$ & $\begin{array}{l}\text { increase in nuclear protein } \\
\text { import and nuclear protein } \\
\text { complex }(5 \text {-fold at } 48 \mathrm{~h}) \\
\text { cell proliferation (cell } \\
\text { hyperplasia and } \\
\text { hypertrophy) }\end{array}$ \\
\hline $\begin{array}{l}\text { Mata- } \\
\text { Greenwood } \\
\text { et al. } 2005 \text { [55] }\end{array}$ & $\begin{array}{l}\text { pulmonary artery } \\
\text { SMCs (animal) }\end{array}$ & $\begin{array}{l}\text { cultured cells } \\
20 \% \text { cyclical stretch }\end{array}$ & $\begin{array}{l}\uparrow \text { VEGF }(2.4 \text {-fold at } 4 \mathrm{~h}) \\
\uparrow \text { TGF- } \beta 1(3 \text {-fold at } 2 \mathrm{~h})\end{array}$ & cell proliferation \\
\hline
\end{tabular}


Table 1 (continued)

\begin{tabular}{|c|c|c|c|c|}
\hline Study & Cell type and origin & Stretch method employed & Genes regulated & Effect on the vessel wall \\
\hline $\begin{array}{l}\text { Albinsson } \\
\text { et al. } 2004 \text { [62] }\end{array}$ & portal vein (rat) & $\begin{array}{l}\text { portal vein organ culture } \\
\text { stretched with } 0.3-0.6 \mathrm{~g} \text { of } \\
\text { weight (equivalent to physio- } \\
\text { logical conditions) for } 72 \mathrm{~h}\end{array}$ & $\begin{array}{l}\uparrow \text { actin polymerisation } \\
\uparrow \text { smooth muscle-specific proteins: } \\
\alpha \text {-actin } \\
\text { calponin } \\
\text { SM22- } \alpha \\
\text { tropomyosin } \\
\text { desmin }\end{array}$ & $\begin{array}{l}\text { maintains the contractile } \\
\text { phenotype of SMCs }\end{array}$ \\
\hline $\begin{array}{l}\text { Cornelissen } \\
\text { et al. } 2004 \text { [51] }\end{array}$ & $\begin{array}{l}\text { saphenous vein } \\
\text { (human) }\end{array}$ & $\begin{array}{l}\text { saphenous vein organ culture } \\
\text { stretched to } 200-250 \mathrm{~mm} \mathrm{Hg} \text { of } \\
\text { pressure for } 2 \mathrm{~min}\end{array}$ & $\begin{array}{l}\uparrow \text { phosphorylated p38 associated with } \\
\text { increased apoptosis in saphenous vein } \\
\text { SMCs }\end{array}$ & apoptosis \\
\hline $\begin{array}{l}\text { Goldman } \\
\text { et al. } 2003 \text { [52] }\end{array}$ & IVC (rat) & $\begin{array}{l}\text { IVC and diaphragm excised and } \\
\text { placed in a pulsatile circulatory } \\
\text { system } \\
\text { exposure to both venous and } \\
\text { arterial pressure (ex vivo culture } \\
\text { model of vein graft) }\end{array}$ & $\begin{array}{l}\downarrow \text { SMC } \alpha \text {-actin filaments } \\
\text { (down to } 19 \% \text { at } 48 \text { h on exposure to } \\
\text { arterial pressure) } \\
\uparrow \text { caspase } 3 \text { (on exposure to arterial } \\
\text { pressure) }\end{array}$ & apoptosis \\
\hline $\begin{array}{l}\text { De Waard } \\
\text { et al. } 2006 \text { [32] }\end{array}$ & $\begin{array}{l}\text { saphenous vein ex vivo } \\
\text { perfusion model } \\
\text { (human) } \\
\text { carotid artery organ } \\
\text { culture (mice) } \\
\text { venous SMCs (human) } \\
\text { SMCs from internal } \\
\text { mammary artery } \\
\text { (human) }\end{array}$ & $\begin{array}{l}\text { saphenous veins placed in } \\
\text { extracorporeal circulation } \\
\text { during bypass surgery and } \\
\text { exposed to autologous (non- } \\
\text { pulsatile) arterial pressure } \\
\text { carotid artery organ culture } \\
\text { exposed to pulsatile stretch of } \\
60-140 \mathrm{~mm} \mathrm{Hg} \text { for } 48 \mathrm{~h} \\
\text { cultured VSMCs exposed to } 10 \% \\
\text { cyclical stretch }\end{array}$ & $\begin{array}{l}\uparrow \text { DNA synthesis ( } 3.5 \text {-fold) } \\
\uparrow \text { PAI- } 1 \text { ( } 8 \text {-fold) } \\
\uparrow \text { TR3 (14-fold after } 1-2 \mathrm{~h} \text { of cyclical } \\
\text { stretch) in VSMCs of veins but not } \\
\text { arteries }\end{array}$ & $\begin{array}{l}\text { change of phenotype of } \\
\text { venous smooth muscles } \\
\text { from contractile into } \\
\text { synthetic phase on exposure } \\
\text { to arterial pressure (arterial } \\
\text { smooth muscles more } \\
\text { resistant to this change) }\end{array}$ \\
\hline
\end{tabular}

ET-B = Endothelin-B; Flk 1 = fetal liver kinase 1; GADD-153 = growth arrest and DNA damage-inducible gene 153; HSP-60 = heat shock protein-60; PAECs = porcine artery endothelial cells; PCNA = proliferating cell nuclear antigen; RCMEs = rat coronary microvascular endothelial cells; SGK = serum-glucocorticoid-induced protein kinase (a serine/threonine protein kinase); SM22- $\alpha=$ smooth muscle cells protein 22 - $\alpha$; Tie $1=$ tyrosine kinase with immunoglobulin-like and epidermal growth factor-like domains 1; Tie2 = tyrosine kinase with immunoglobulin-like and epidermal growth factor-like domains 2 ; TGF $=$ transforming growth factor; TR3 = human orphan receptor TR3.

Pulsatile stretch of $20 \%$ causes rabbit aorta VSMCs to enter and complete the cell cycle and induces cell hyperplasia and hypertrophy [60]. In human aortic SMCs exposed to cyclical strain, DNA microhybridisation analyses identified 5,000 putative functional genes, but only 3 were shown to be upregulated, including cyclooxygenase-1 (COX-1), tenasin and plasminogen activator inhibitor-1 (PAI-1), whilst downregulated genes included thrombomodulin and MMP-1. Tenasin and PAI-1 modulate ECM, and COX regulates VSMC proliferation [61].

\section{Effect on VSMC Phenotype}

Mechanical stretch above a certain physiological threshold is required to maintain VSMCs' differentiated phenotype (contractile) [36]. For instance, exposure of a murine portal vein organ culture to physiological stretch increased actin polymerisation and proteins associated with a contractile cytoskeletal phenotype [62]. However, when the pressure is increased, the VSMC phenotype shifts from contractile to synthetic. This effect is seen when the vein is subjected to conditions akin to a vein bypass graft. An increase in PAI-1 and DNA synthesis in venous SMCs is noticed. The phenotype of arterial SMCs remains stable at a relatively higher pressure as compared to veins, owing to arteries being exposed to higher pressures physiologically [32].

Similarly, stretch in a SMC culture model switches the SMC contractile phenotype to a synthetic one, as shown by a loss of VSMC myosin, an increase in ECM and protein synthesis and a proliferative state $[63,64]$. 


\section{Stretch-Regulated Genes Affecting the Inflammatory Response and Vasomotor Activity in Blood Vessels}

Exposure of HUVECs and saphenous vein ECs to 10\% cyclical stretch increases the expression of a vasoconstrictor endothelin-1 (ET-1) messenger RNA (mRNA) but has no effect on endothelial nitric oxide synthase transcription. In contrast, shear stress increases endothelial nitric oxide synthase expression and decreases ET-1 expression. This suggests that the ET-1 activity is controlled by the balance between the two forces. The combination of these two mechanical forces acts to neutralise the effect on ET-1 (for expression of stretch-induced genes in inflammation, see table 2) $[65,66]$. In addition to causing vasoconstriction, stretch-induced ET-1 mRNA from arterial ECs has been reported to affect VSMCs by increasing apoptosis [67]. Various vasoactive substances induced by cyclical strain in ECs include nitric oxide, prostacyclin, tissue plasminogen activator, reactive oxygen species (ROS) and monocyte chemotactic protein-1 (MCP-1) [68-72].

Exposure of HUVECs to cyclical stretch causes nuclear migration of zyxin (a zinc finger protein), which acts to coordinate the expression of proinflammatory genes such as interleukin (IL)-8, vascular cell adhesion molecule (VCAM) and intercellular adhesion molecule (ICAM) [73]. Similarly, an upregulation of inflammatory mediators, including IL- 8 and MCP, has been seen in HUVECs in response to cyclical stretch [74]. Continuous stretch also upregulates the proinflammatory gene IL-6 through NFкB in HUVECs [75]. IL-6 is also upregulated in mouse artery VSMCs exposed to cyclical stretch for $2 \mathrm{~h}$ [76]. NFKB also plays a role in COX-2 transcription in HUVECs exposed to cyclical stretch [77]. COX-2 and thromboxane synthase enzymes are involved in the stepwise breakdown of arachidonic acid into prostacyclin and thromboxane-A2. Prostacyclin is a vasodilator and has anti-inflammatory and anti-platelet activity, and thromboxane-A2 is a vasoconstrictor and promoter of platelet aggregation. Upregulation of these genes suggests that vessel stretch may initiate an inflammatory response in ECs resulting in the activation of adhesion molecules and cytokines leading to endothelial barrier disruption and increased vascular permeability.

Stretch increases the expression of C-reactive protein (CRP) mRNA and protein in saphenous vein and internal mammary artery rings exposed to stretch [78]. CRP is a nonspecific marker of inflammation and is considered an independent risk factor for atherosclerosis and atherosclerosis-related diseases [79, 80]. Elevated CRP has been measured in the blood of patients with high systemic or local strain including essential hypertension [81], abdominal aortic aneurysms [82] and vein grafts in coronary bypass surgery [83]. CRP directly activates inflammatory cells, MMPs and various cytokines [80, 84]. Locally produced CRP in vessel walls may therefore be an important mediator in the stretch-induced inflammatory response.

\section{Mechanical Stretch and MMPs}

ECM interlinks the cellular components such as endothelium and VSMCs and consists of collagen, proteoglycans, elastin, glycoproteins and fibronectin. It is a dynamic structure and maintains integrity and homoeostasis through its interactions with the cellular components [85]. MMPs are zinc-dependant endopeptidases and belong to the family of proteases called metzincins. Their function is to cleave most of the constituents of ECM [15]. Out of 23 identified in humans to date, 14 are found in vascular tissue [86]. MMPs are produced as inactive pro-enzymes (zymogens) and are activated by various exogenous and endogenous stimuli [87]. Their activity is further controlled by their endogenous tissue inhibitors (tissue inhibitors of metalloproteinases) $[85,88,89]$.

Stretch regulates MMPs in animal and human cells (for stretch-induced genes affecting ECM, see table 3) and organ culture models and in turn affects the matrix metabolism in vascular tissue [90]. Upregulation of MMP-2 and -14 expression in venous ECs and MMP-2 in capillary ECs has been observed [91, 92]. Increases in MMP-2 and MMP-9 expression have also been reported in venous and arterial SMCs and fibroblasts subjected to mechanical stretch [93-95].

Increases in the magnitude and duration of vein wall tension in segments of rat inferior vena cava (IVC) were associated with reduced contraction and overexpression of MMP-2 and MMP-9 [96]. MMP-2 and -9 belong to the gelatinase group of MMPs, which act to digest denatured collagens. MMP-2 and MMP-9 were also found to induce significant relaxation of rat IVC, proposed to occur through VSMC hyperpolarisation and activation of large-conductance calcium-dependent potassium channels, suggesting that MMPs may play a role in the early stages of venous dilation secondary to high venous pressure [97]. Using a similar model of IVC rings, Lim et al. 
Table 2. Mechanical stretch induces expression of genes in ECs and VSMCs affecting vasomotor activity and the inflammatory response

\begin{tabular}{|c|c|c|c|c|}
\hline Study & Cell type and origin & Stretch method employed & Genes regulated & Effect on the vessel wall \\
\hline $\begin{array}{l}\text { Toda et al. } \\
2008[65]\end{array}$ & HUVECs & $\begin{array}{l}\text { cultured cells } \\
10 \% \text { cyclical stretch }\end{array}$ & $\uparrow$ ET-1 (1.6-fold at $24 \mathrm{~h})$ & $\begin{array}{l}\text { vasoconstriction } \\
\text { apoptotic }\end{array}$ \\
\hline $\begin{array}{l}\text { Wojtowicz } \\
\text { et al. } 2010 \\
\text { [73] }\end{array}$ & HUVECs & $\begin{array}{l}\text { cultured cells } \\
10 \% \text { cyclical stretch }\end{array}$ & $\begin{array}{l}\text { cytoskeletal protein zyxin } \\
\text { translocation into nucleus and } \\
\text { increased expression of } \\
\text { IL-8, VCAM, ICAM }\end{array}$ & $\begin{array}{l}\text { apoptotic } \\
\text { chemotaxis } \\
\text { intercellular adhesions } \\
\text { molecules promoting } \\
\text { adhesion of cells to } \\
\text { neutrophils, macrophages }\end{array}$ \\
\hline $\begin{array}{l}\text { Kobayashi } \\
\text { et al. } 2003 \\
{[75]}\end{array}$ & HUVECs & $\begin{array}{l}\text { cultured cells } \\
\text { continuous stretch of } 125 \text { or } 150 \%\end{array}$ & $\begin{array}{l}\uparrow \text { IL-6 (4-fold at } 2 \mathrm{~h} \text { ) } \\
\text { NFкB mediated }\end{array}$ & $\begin{array}{l}\text { proinflammatory and anti- } \\
\text { inflammatory cytokines }\end{array}$ \\
\hline $\begin{array}{l}\text { Zhao et al. } \\
2009 \text { [77] }\end{array}$ & HUVECs & $\begin{array}{l}\text { cultured cells } \\
10 \% \text { cyclical stretch }\end{array}$ & $\begin{array}{l}\uparrow \mathrm{COX}-2(2.5 \text {-fold within } 3 \mathrm{~h}) \\
\uparrow \text { thromboxane-A2 synthase } \\
\text { (NFkB mediated) }\end{array}$ & $\begin{array}{l}\text { regulation of inflammation } \\
\text { and platelet activity } \\
\text { control of vasomotor tone }\end{array}$ \\
\hline $\begin{array}{l}\text { Wung et al. } \\
1997[72]\end{array}$ & HUVECs & $\begin{array}{l}\text { cultured cells } \\
12 \% \text { cyclical stretch }\end{array}$ & $\uparrow \mathrm{MCP}-1$ & $\begin{array}{l}\text { chemotactic to monocytes } \\
\text { and macrophages }\end{array}$ \\
\hline $\begin{array}{l}\text { Okada et al. } \\
1998[74]\end{array}$ & HUVECs & $\begin{array}{l}\text { cultured cells } \\
15 \% \text { cyclical stretch }\end{array}$ & $\begin{array}{l}\uparrow \text { IL- } 8 \text { (2.8-fold at } 6 \mathrm{~h}) \\
\uparrow \mathrm{MCA} / \mathrm{MCP}-1(2.2 \text {-fold at } 3 \mathrm{~h})\end{array}$ & $\begin{array}{l}\text { chemotactic factor for } \mathrm{T} \\
\text { lymphocytes and VSMCs } \\
\text { mitogenic for VSMCs }\end{array}$ \\
\hline $\begin{array}{l}\text { Iba et al. } \\
1991[70]\end{array}$ & $\begin{array}{l}\text { saphenous vein } \\
\text { endothelial cells (human) }\end{array}$ & $\begin{array}{l}\text { cultured cells } \\
7-24 \% \text { cyclical stretch }\end{array}$ & $\begin{array}{l}\uparrow \text { tissue plasminogen activator at } \\
>7 \% \text { stretch }\end{array}$ & fibrinolytic activity \\
\hline $\begin{array}{l}\text { Tsukurov } \\
\text { et al. } 2000 \\
\text { [66] }\end{array}$ & $\begin{array}{l}\text { saphenous vein } \\
\text { endothelial cells (human) }\end{array}$ & $\begin{array}{l}\text { cultured cells } \\
\text { pulsatile pressure and cyclical strain }\end{array}$ & $\uparrow \mathrm{ET}-1$ & $\begin{array}{l}\text { vasoconstriction and } \\
\text { regulation of apoptosis }\end{array}$ \\
\hline $\begin{array}{l}\text { Casey et al. } \\
2001[68]\end{array}$ & $\begin{array}{l}\text { saphenous vein } \\
\text { endothelial cells (human) }\end{array}$ & $\begin{array}{l}\text { cells cultured on a silicone tube exposed } \\
\text { to similar conditions as seen in arteries } \\
(120 / 80 \mathrm{~mm} \mathrm{Hg}, 115 \mathrm{ml} / \mathrm{min} \text { flow, } \\
2 \% \text { cyclical stretch and } 4.8-9.4 \text { dynes/ } \\
\left.\mathrm{cm}^{2} \text { shear stress }\right)\end{array}$ & $\begin{array}{l}\uparrow \text { endothelial nitric oxide } \\
\text { (absence of pulsatility, cyclical } \\
\text { strain and flow resulted in } \\
\text { significantly lower production of } \\
\text { nitric oxide) }\end{array}$ & vasodilation \\
\hline $\begin{array}{l}\text { Zampetaki } \\
\text { et al. } 2005 \\
{[76]}\end{array}$ & aortic VSMCs (rat) & $\begin{array}{l}\text { cultured cells } \\
7,15 \text { and } 20 \% \text { cyclical stretch }\end{array}$ & $\begin{array}{l}\uparrow \text { IL-6 (NFKB mediated) peaked } \\
\text { at } 3 \mathrm{~h}\end{array}$ & $\begin{array}{l}\text { proinflammatory and anti- } \\
\text { inflammatory cytokines }\end{array}$ \\
\hline $\begin{array}{l}\text { Huang et al. } \\
2009 \text { [78] }\end{array}$ & $\begin{array}{l}\text { saphenous vein and } \\
\text { internal mammary artery } \\
\text { rings (human) }\end{array}$ & $\begin{array}{l}\text { saphenous vein and internal mammary } \\
\text { artery rings organ culture } \\
\text { stretched with } 0,1,2,3 \text { and } 5 \mathrm{~g} \text { of wall } \\
\text { tension for } 20 \mathrm{~min}\end{array}$ & $\begin{array}{l}\uparrow \mathrm{CRP}(>9 \text {-fold in internal } \\
\text { memory rings and }>10 \text {-fold in } \\
\text { saphenous vein rings with } 3 \mathrm{~g} \text { of } \\
\text { weight) }\end{array}$ & $\begin{array}{l}\text { non-specific marker of } \\
\text { inflammation } \\
\text { considered a risk factor for } \\
\text { hypertension and } \\
\text { cardiovascular diseases }\end{array}$ \\
\hline
\end{tabular}

MCA = Monocyte chemotactic antigen.

[98] found increased expression of HIF- $1 \alpha$ and $-2 \alpha$ in association with MMP-2 and MMP-9 gene expression, highlighting the significance of MMP and HIF gene expression in venous wall remodelling under stretch. MMP-2 expression has been noticed in aortic tissue rings exposed to $100 \mathrm{~mm} \mathrm{Hg}$ of pressure [99]. Porcine carotid arteries subjected to increases in axial strain (elongation) in an ex vivo perfusion circuit also showed an elevation of MMP-2 and MMP-9 protein expression [33].

Mechanical Stretch and Vascular Gene Expression

\section{Evidence from Studies Using Experimental in vivo Vein Bypass Grafts or Arteriovenous Fistula Models}

The effects of stretch induced by arterial pressure on the vein wall have been established by in vivo experimental models of veins connected to the arterial circulation [developing a bypass graft or arteriovenous (AV) fistula] $[34,35,100]$. Expression of genes promoting proliferation of VSMCs in the neointima of an in vivo vein bypass graft 
Table 3. Mechanical stretch induces expression of genes regulating ECM in vascular cells

\begin{tabular}{|c|c|c|c|c|}
\hline Study & Cell type and origin & Stretch method employed & Genes regulated & Effect on the vessel wall \\
\hline $\begin{array}{l}\text { Wang et al. } \\
2003[91]\end{array}$ & HUVECS & $\begin{array}{l}\text { cultured cells } \\
20 \% \text { cyclical stretch }\end{array}$ & $\begin{array}{l}\uparrow(3 \text {-fold at } 12 \mathrm{~h} \text { ) expression of: } \\
\text { MMP- } 2 \\
\text { MMP- } 14 \\
(\text { mediated by TNF- } \alpha \text { ) }\end{array}$ & $\begin{array}{l}\text { ECM remodelling } \\
\text { (MMPs degrade ECM) }\end{array}$ \\
\hline $\begin{array}{l}\text { Milkiewicz } \\
\text { and Haas } \\
2005[92]\end{array}$ & $\begin{array}{l}\text { skeletal muscle } \\
\text { capillary ECs (animal) }\end{array}$ & $\begin{array}{l}\text { static stretching of rat skeletal } \\
\text { muscles }\end{array}$ & $\begin{array}{l}\uparrow \text { MMP-2 (2.5-fold) } \\
\uparrow \text { HIF-1 } \alpha \text { (13.5-fold) }\end{array}$ & $\begin{array}{l}\text { ECM remodelling } \\
\text { HIF regulates VEGF and other HIF- } \\
\text { related genes }\end{array}$ \\
\hline $\begin{array}{l}\text { Stanley et al. } \\
2000[64]\end{array}$ & $\begin{array}{l}\text { human saphenous vein } \\
\text { SMCs }\end{array}$ & $\begin{array}{l}\text { cultured cells } \\
22 \% \text { cyclical stretch }\end{array}$ & $\begin{array}{l}\uparrow \text { collagen } \alpha 1(102 \pm 30 \%) \\
\uparrow \text { fibronectin protein } \\
(50 \pm 21 \%)\end{array}$ & $\begin{array}{l}\text { major component of type } 1 \text { collagen } \\
\text { fibronectin (major component of } \\
\text { ECM) plays a significant role in cell- } \\
\text { cell interaction, adhesion, } \\
\text { differentiation and growth }\end{array}$ \\
\hline $\begin{array}{l}\text { Asanuma } \\
\text { et al. } 2003 \\
{[95]}\end{array}$ & $\begin{array}{l}\text { human saphenous vein } \\
\text { SMCs }\end{array}$ & $\begin{array}{l}\text { cultured cells } \\
5 \% \text { stationary and } 5 \% \text { cyclical stretch }\end{array}$ & $\begin{array}{l}\uparrow \text { MMP-2 (50-fold at } 24 \mathrm{~h} \text { ) } \\
\uparrow \text { MMP-9 } \\
\text { (both with stationary as } \\
\text { compared to cyclical or no } \\
\text { stretch) }\end{array}$ & $\begin{array}{l}\text { ECM remodelling } \\
\text { (MMPs degrade ECM) }\end{array}$ \\
\hline $\begin{array}{l}\text { Grote et al. } \\
2003[93]\end{array}$ & aortic VSMCs (mice) & $\begin{array}{l}\text { cultured cells } \\
15 \% \text { cyclical stretch }\end{array}$ & $\begin{array}{l}\uparrow(>2 \text {-fold at } 3 \text { h) expression of: } \\
\text { MMP-2 } \\
\text { PAI-1 } \\
\text { CD44 } \\
\text { integrin- } \alpha\end{array}$ & $\begin{array}{l}\text { ECM remodelling } \\
\text { inhibition of fibrinolysis } \\
\text { CD44: } \\
\text { cell-cell interaction, adhesions and } \\
\text { migration } \\
\text { integrin- } \alpha \text { : } \\
\text { cell attachment to ECM and signal } \\
\text { transduction }\end{array}$ \\
\hline $\begin{array}{l}\text { Tamura et al. } \\
2000[90]\end{array}$ & $\begin{array}{l}\text { VSMCs } \\
\text { (animal) }\end{array}$ & $\begin{array}{l}\text { cultured cells } \\
20 \% \text { cyclical stretch }\end{array}$ & $\begin{array}{l}\uparrow \text { type } 1 \text { collagen } \\
(4.2 \text {-fold at } 12 \mathrm{~h}) \\
\uparrow \text { fibronectin }(3.5 \text {-fold at } 12 \mathrm{~h}) \\
\uparrow \mathrm{ACE}\end{array}$ & $\begin{array}{l}\text { ECM remodelling (fibronectin plays } \\
\text { a significant role in cell-cell adhesion, } \\
\text { differentiation and growth) }\end{array}$ \\
\hline $\begin{array}{l}\text { Lim et al. } \\
2011[31]\end{array}$ & IVC rings (rat) & $\begin{array}{l}\text { IVC rings exposed to } 2 \mathrm{~g} \\
(84.3 \mathrm{~mm} \mathrm{Hg}) \text { of wall tension in an } \\
\text { ex vivo model for } 18 \mathrm{~h}\end{array}$ & $\begin{array}{l}\uparrow \operatorname{HIF}-1 \alpha \\
\uparrow \operatorname{HIF}-2 \alpha \\
\uparrow \mathrm{MMP}-2 \\
\uparrow \mathrm{MMP}-9\end{array}$ & $\begin{array}{l}\text { HIF regulates VEGF and other HIF- } \\
\text { related genes } \\
\text { ECM remodelling }\end{array}$ \\
\hline $\begin{array}{l}\text { Raffetto } \\
\text { et al. } 2008 \\
{[96]}\end{array}$ & IVC rings (rat) & $\begin{array}{l}\text { IVC rings subjected to } 2 \mathrm{~g} \text { of tension } \\
\text { (equivalent to } 83.4 \mathrm{~mm} \mathrm{Hg} \text { ) for } 24 \mathrm{~h}\end{array}$ & $\begin{array}{l}\uparrow \text { MMP-2 } \\
\uparrow \text { MMP-9 }\end{array}$ & ECM remodelling \\
\hline $\begin{array}{l}\text { Ruddy et al. } \\
2010 \text { [99] }\end{array}$ & $\begin{array}{l}\text { thoracic aortic ring } \\
\text { apparatus (murine) }\end{array}$ & $\begin{array}{l}\text { aortic rings subjected to tension } \\
\text { equivalent to } 0,70,80 \text { and } \\
100 \mathrm{~mm} \mathrm{Hg} \text { pressure for } 3 \mathrm{~h}\end{array}$ & $\begin{array}{l}\uparrow \mathrm{MMP}-2 \text { (1.57-fold at } 100 \mathrm{~mm} \\
\mathrm{Hg})\end{array}$ & ECM remodelling \\
\hline $\begin{array}{l}\text { Nichol et al. } \\
2009 \text { [33] }\end{array}$ & $\begin{array}{l}\text { carotid arteries } \\
\text { (porcine) }\end{array}$ & $\begin{array}{l}\text { carotid arteries cannulated onto } \\
\text { stainless steel rods in a chamber } \\
\text { connected to a self-contained } \\
\text { perfusion loop } \\
\text { arteries exposed to reduced or } \\
\text { arterial haemodynamics for } 9 \text { days } \\
\text { and } \\
\text { either maintained their in situ length } \\
\text { or elongated to } 50 \% \text { of in situ length }\end{array}$ & $\begin{array}{l}\uparrow M M P-2 \text { and }-9 \text { protein } \\
\text { expression by increased axial } \\
\text { strain (elongation) and } \\
\text { reduced haemodynamics } \\
\text { individually } \\
\uparrow \text { MMP-9 by combined } \\
\text { reduced haemodynamics and } \\
\text { increased axial strain }\end{array}$ & ECM remodelling \\
\hline
\end{tabular}

$\mathrm{ACE}=$ Angiotensin-converting enzyme; TNF- $\alpha=$ tumour necrosis factor- $\alpha$. 
Table 4. Changes in vein wall and altered gene expression on exposure to arterial pressure (in vivo AV fistula or vein bypass graft model)

\begin{tabular}{|c|c|c|c|c|}
\hline Study & Model type & Stretch method employed & Genes regulated & $\begin{array}{l}\text { Effect on the vessel } \\
\text { wall }\end{array}$ \\
\hline $\begin{array}{l}\text { Takase et al. } \\
2004[103]\end{array}$ & $\begin{array}{l}\text { femoral artery and vein } \\
\text { fistula formation (rat) }\end{array}$ & $\begin{array}{l}\text { AV fistula development between } \\
\text { femoral artery and vein for } 21 \\
\text { days }\end{array}$ & $\begin{array}{l}\uparrow \text { granulocyte, monocyte, } \\
\text { T lymphocyte infiltration of valve } \\
\uparrow \text { P-selectin and ICAM- } 1 \text { in ECs }\end{array}$ & $\begin{array}{l}\text { increased } \\
\text { inflammatory } \\
\text { reaction } \\
\text { extensive apoptosis }\end{array}$ \\
\hline $\begin{array}{l}\text { Pyle et al. } \\
2010[125]\end{array}$ & $\begin{array}{l}\text { saphenous veins } \\
\text { retrieved from coronary } \\
\text { artery bypass surgery } \\
\text { VSMCs from human } \\
\text { aortic tissue }\end{array}$ & $\begin{array}{l}\text { arterialised saphenous veins from } \\
\text { coronary artery bypass surgery } \\
\text { VSMCs subjected to cyclical } \\
\text { stretch of } 15-20 \%\end{array}$ & $\begin{array}{l}\uparrow \text { MMP-2 (2.9-fold at } 48 \mathrm{~h}) \\
\uparrow \text { elastin }(8.8 \text {-fold at } 72 \mathrm{~h}) \\
\uparrow \text { AIE genes in VSMCs exposed to cyclical } \\
\text { stretch: } \\
\text { sciellin }(4.6 \text {-fold) } \\
\text { periplakin }(1.5 \text {-fold) } \\
\text { SPRR3 genes (4.9-fold) }\end{array}$ & ECM remodelling \\
\hline $\begin{array}{l}\text { Chung et al. } \\
2005[35]\end{array}$ & $\begin{array}{l}\text { carotid artery bypass } \\
\text { graft using internal } \\
\text { jugular vein (porcine) }\end{array}$ & $\begin{array}{l}\text { arterialised internal jugular vein } \\
\text { for } 2 \text { weeks }\end{array}$ & $\begin{array}{l}\uparrow \mathrm{MMP}-2 \\
\uparrow \mathrm{MMP}-9 \\
\downarrow \mathrm{TIMP}-1 \\
\downarrow \mathrm{TIMP}-2\end{array}$ & $\begin{array}{l}\text { ECM remodelling } \\
\text { neointima formation } \\
\text { in arterialised vein }\end{array}$ \\
\hline $\begin{array}{l}\text { Misra et al. } \\
2008[34]\end{array}$ & $\begin{array}{l}\text { femoral artery and vein } \\
\text { fistula formation (rat) }\end{array}$ & $\begin{array}{l}\text { AV fistula development between } \\
\text { femoral artery and vein for } 28 \\
\text { days (exposing veins to arterial } \\
\text { pressure) }\end{array}$ & $\begin{array}{l}\uparrow \text { pro-MMP- } 2 \\
\uparrow \text { active MMP- } 2 \text { at days } 14 \text { and } 28 \\
\uparrow \text { pro-MMP- } 9 \text { at day } 28 \\
\text { (at the site of venous stenosis) } \\
\uparrow \text { intima to media ratio by } 28 \% \text { ( } \alpha \text {-actin) }\end{array}$ & $\begin{array}{l}\text { ECM remodelling } \\
\text { linked to vein graft } \\
\text { narrowing and failure }\end{array}$ \\
\hline $\begin{array}{l}\text { Pascarella } \\
\text { et al. } 2008 \\
{[100]}\end{array}$ & $\begin{array}{l}\text { femoral artery and vein } \\
\text { fistula formation (rat) }\end{array}$ & $\begin{array}{l}\text { AV fistula development between } \\
\text { femoral artery and vein for } 21 \\
\text { days (exposing veins to arterial } \\
\text { pressure) }\end{array}$ & $\begin{array}{l}\uparrow \text { MMP-2 } \\
\uparrow \text { MMP-9 } \\
\uparrow \text { granulocyte and macrophage infiltration } \\
\text { into the venous wall and valve }\end{array}$ & $\begin{array}{l}\text { ECM remodelling } \\
\text { vein valve scarring }\end{array}$ \\
\hline
\end{tabular}

SPRR3 = Small proline-rich protein 3; TIMP = tissue inhibitor of metalloproteinase.

model suggests the important role of stretch in the development of neointima in arterialised veins (table 4) [101]. The potential for venous hypertension to initiate vein wall and valvular damage leading to venous insufficiency is shown in a rat model by inducing acute venous hypertension through the creation of an $\mathrm{AV}$ fistula between the femoral artery and vein $[34,100,102,103]$. The limbs with the AV fistula developed venous reflux and oedema, which worsened over time (3-6 weeks) compared to control limbs. Valvular and vein wall injury, fibrosis, increased infiltration of inflammatory cells including granulocytes, monocytes and macrophages and upregulation of P-selectin and ICAM-1 expression were found in saphenous vein walls in the presence of an AV fistula compared to those without $[100,102,103]$. Interestingly, rats that received oral treatment with micronised purified flavonoid fraction (a drug used in the treatment of CVI) demonstrated reduced leg oedema and venous reflux in response to the AV fistula [100].

Moreover, MMP-2 and MMP-9 were found to be overexpressed at the site of neointima in both the AV fistula and vein bypass graft model after 2 weeks of exposure to arterial pressure (further increased after 4 weeks) [34, 35, 100]. Increased scarring of the venous valve was also noted [100]. These models clearly explain the important role of MMPs in the development of neointimal lesions in arterialised veins.

\section{ROS and Stretch}

ROS are produced by steady reduction of oxygen and include both unstable free radicals (such as superoxide and hydroxyl radicals) and stable non-free radicals (such as hydrogen peroxide). Increased production of ROS is implicated in the pathogenesis of vascular diseases such as hypertension, atherosclerosis, diabetic vascular complications and heart failure $[104,105]$. ROS are produced by all vascular cell types including ECs, VSMCs and adventitial cells $[55,106,107]$. Pressure-induced mechanical stretch generates ROS from sources including xanthine oxidoreductase, nicotinamide adenine dinucleo- 
tide phosphate oxidases and uncoupled nitric oxide synthases [69, 104, 108, 109]. These cyclic stretch-induced ROS further activate MAPK signalling, increasing $\mathrm{NF} \kappa \mathrm{B}$ transcription factor production and, hence, playing a significant role in upregulating stretch-induced gene transcription (fig. 2) [110-112]. ROS have been linked with stretch-induced upregulation of VCAM-1, MMP-2, VEGF, IL-1, IL- 6 and MCP-1 [55, 72, 93, 104].

\section{Alterations in Gene Expression with Stretch: Similarities with the Biological Features of Vascular Diseases}

\section{Varicose Veins}

Several risk factors have been identified for primary varicose vein disease including age, sex, genetics and family history, pregnancy and occupation involving prolonged standing [113]. Primary wall changes including intimal hyperplasia, smooth muscle hypertrophy, alteration in elastin and collagen content and imbalances of MMPs and their tissue inhibitors have been reported in the context of varicose veins $[114,115]$.

Infiltration of inflammatory cells and increased expression of surface markers including VCAM-1 and ICAM-1 have been seen in the ECs of varicose veins [114, $116,117]$. Elevation of venous pressure activates inflammatory processes in the venous system including expression of E-selectin, ICAM-1 and VCAM-1 in the plasma obtained from leg veins of patients with and without varicose veins [118]. In another study, high venous pressure induced through venous occlusion with an inflated cuff elevated the expression of IL-1 $\beta$, IL- 6 and tumour necrosis factor- $\alpha$ in patients with and without varicose veins, and more so in the former $[119,120]$. Imbalances of vasoconstrictor and vasodilator levels have been reported, with a reduction in vasoconstrictors and an upregulation of vasodilators reported in the context of varicose veins $[15,114]$. MMP-2 and -9 are also implicated in the development of varicose veins and CVI [87].

\section{Chronic Venous Insufficiency}

The mechanical stretch seen with blood stasis in the legs has been proposed as a mechanism responsible for primary vein wall changes; however, the evidence remains inconclusive. Several hypotheses, such as the white cell trapping theory, fibrin cuff theory and growth factor trapping theory, have been considered in the development of CVI [2]. Inflammation and an imbalance of growth factors are considered to play a significant role in the pathogenesis of CVI, causing movement of capillary contents into the interstitial space, hyperpigmentation, oedema and ulceration. For example, upregulation of transforming growth factor- $\beta$, which has pro-proliferative and anti-inflammatory effects, is associated with healing of venous ulceration [121]. MMP-9 along with endothelial membrane intercellular adhesion molecule 1 and L-selectin are found to be elevated in blood samples taken from lower-extremity veins following $30 \mathrm{~min}$ of postural stasis, suggesting an interaction between proteolytic enzymes, ECs and leukocytes in situations resembling venous hypertension [122].

The majority of studies on cell culture models have looked at the effect of cyclical stretch. This approach limits the application of results to explaining the pathogenesis of venous diseases where the stretch pattern is more static than cyclical. Therefore, there remains a need for experimental evidence to correlate the role of static stretch in the pathogenesis of varicose veins and CVI. A better understanding of the impact of stretch due to blood stasis and its effect on the vessel wall may help open new therapeutic avenues for arterial and venous conditions.

\section{Vein Graft Disease}

Cellular changes such as loss of the EC layer, intimal hyperplasia, SMC proliferation and migration into the intima are reported in veins used as a conduit in arterial bypass leading to graft stenosis or occlusion [21]. Davies et al. [123] and Wilson et al. [124] have shown diffuse changes in intimal hyperplasia and muscular hypertrophy in saphenous and cephalic veins prior to their use in bypass surgery, suggesting that pre-existing disease may predispose vein grafts to stenosis due to inherent susceptibility of diseased veins to intimal hyperplasia.

Certain genes are isolated under physiological conditions in arteries but not veins. Arterial intima-enriched (AIE) genes are expressed by VSMCs and include sciellin, periplakin and small proline-rich protein-3 (SPRR3). AIE proteins are largely cytoskeletal and contribute to the protective properties of stratified epithelium, but their role in vascular tissue is unclear. Exposure to $24-72 \mathrm{~h}$ of stretch increases the expression of AIE genes in human arterial cells. Expression of AIE genes has been seen in arterialised saphenous veins (used as a conduit for coronary artery bypass surgery), suggesting that under conditions of luminal stretch, gene expression in veins approaches that seen in arteries [125]. 
By further understanding the differential gene expression and specific cellular pathways responsible for initiating and potentiating the pathological vein wall remodelling seen with vein arterialisation when exposed to pressure, development of putative therapeutic agents will be facilitated which may be employed in pre-conditioning veins prior to or during bypass graft surgery. The aim in this context is to improve long-term vein graft patency, reducing the death and limb loss related to vein bypass graft failure.

Aneurysmal and Atherosclerotic Arterial Diseases and Similarities with Venous Diseases

In aneurysmal arterial disease, inflammation is present with a cascade activating cytokines, chemokines, MMPs and ROS. In patients with abdominal aortic aneurysms, the expression of aortic wall MMP-9 was associated with aneurysm diameter [126]. Weakness of the medial layer and arterial dilation results in susceptibility to further enlargement with continued exposure to high pressure and, ultimately, rupture. Atherosclerotic arterial disease is also characterised by interaction between multiple vascular cell types with activation of a complex and self-perpetuating inflammatory cascade, again with protease activation [127].

Evidence has shown similarities among arterial and venous conditions. Exposure to altered pressure stretch and/or shear stress in both arteries and veins results in activation of inflammation and remodelling of ECM. This results in the development of atherosclerotic lesions in arteries and arterialised veins. Veins have been shown to require less pressure than arteries to show alterations in their gross morphology. For instance, in a recent study, animal internal jugular vein and carotid arteries were subjected to increasing degrees of distending pressures, and the authors demonstrated that veins buckle at a much lower pressure than arteries [128]. This has clinical relevance in conditions where prolonged intraluminal pressure-induced stretch may lead to constant buckling, including varicose veins, venous valvular insufficiency, diabetic retinopathy and vein grafts [128].

\section{Conclusion}

Modulation of gene expression by stretch is seen in both vascular ECs and VSMCs. The effects of these transcriptional alterations and subsequent protein production lead to changes in cell growth and apoptosis, increased cytokine secretion, upregulation of adhesion molecules on ECs and phenotypic alteration in VSMCs. Similarly, the effect of stretch on vascular cells results in imbalances of MMPs and their inhibitors, in turn altering the composition of the ECM.

\section{References}

1 Giles TD, et al: Expanding the definition and classification of hypertension. J Clin Hypertens (Greenwich) 2005;7:505-512.

$\checkmark 2$ Eberhardt RT, Raffetto JD: Chronic venous insufficiency. Circulation 2005;111:2398409.

3 Lemarie CA, Tharaux PL, Lehoux S: Extracellular matrix alterations in hypertensive vascular remodeling. J Mol Cell Cardiol 2010;48:433-439.

-4 Lehoux S, Tedgui A: Cellular mechanics and gene expression in blood vessels. J Biomech 2003;36:631-643

5 Leung DY, Glagov S, Mathews MB: Elastin and collagen accumulation in rabbit ascending aorta and pulmonary trunk during postnatal growth. Correlation of cellular synthetic response with medial tension. Circ Res 1977;41:316-323.

6 Langille BL, Brownlee RD, Adamson SL: Perinatal aortic growth in lambs: relation to blood flow changes at birth. Am J Physiol 1990;259:H1247-H1253.

Mechanical Stretch and Vascular Gene Expression
Levy BI, et al: Effects of chronic inhibition of converting enzyme on mechanical and structural properties of arteries in rat renovascular hypertension. Circ Res 1988;63: 227-239.

8 Intengan HD, Schiffrin EL: Vascular remodeling in hypertension: roles of apoptosis, inflammation, and fibrosis. Hypertension 2001;38:581-587.

-9 Ailawadi G, Eliason JL, Upchurch GR Jr: Current concepts in the pathogenesis of abdominal aortic aneurysm. J Vasc Surg 2003; 38:584-588.

10 Alexander RW: Theodore Cooper Memorial Lecture. Hypertension and the pathogenesis of atherosclerosis. Oxidative stress and the mediation of arterial inflammatory response: a new perspective. Hypertension 1995;25:155-161.

11 Ross R: Atherosclerosis - an inflammatory disease. N Engl J Med 1999;340:115-126.

12 Crowther MA: Pathogenesis of atherosclerosis. Hematology Am Soc Hematol Educ Program 2005:436-441.
13 Cheng C, et al: Atherosclerotic lesion size and vulnerability are determined by patterns of fluid shear stress. Circulation 2006;113: 2744-2753.

14 Thubrikar MJ, Robicsek F: Pressure-induced arterial wall stress and atherosclerosis. Ann Thorac Surg 1995;59:1594-603.

15 Raffetto JD, Khalil RA: Mechanisms of varicose vein formation: valve dysfunction and wall dilation. Phlebology 2008;23:85-98.

16 Bhardwaj S, Roy H, Yla-Herttuala S: Gene therapy to prevent occlusion of venous bypass grafts. Expert Rev Cardiovasc Ther 2008;6:641-652.

17 Tsui JC, et al: Localization of nitric oxide synthase in saphenous vein grafts harvested with a novel 'no-touch' technique: potential role of nitric oxide contribution to improved early graft patency rates. J Vasc Surg 2002;35: 356-362.

18 Ballard JL, Mills JL Sr: Surgical management of critical limb ischemia. Tech Vasc Interv Radiol 2005;8:169-174. 
19 Golledge J: Lower-limb arterial disease. Lancet 1997;350:1459-1465.

20 Zou Y, et al: Mouse model of venous bypass graft arteriosclerosis. Am J Pathol 1998;153: 1301-1310.

21 Parang P, Arora R: Coronary vein graft disease: pathogenesis and prevention. Can J Cardiol 2009;25:e57-e62.

22 Mofidi R, et al: Significance of the early postoperative duplex result in infrainguinal vein bypass surveillance. Eur J Vasc Endovasc Surg 2007;34:327-332.

23 Szilagyi DE, et al: Biologic fate of autogenous vein implants as arterial substitutes: clinical, angiographic and histopathologic observations in femoro-popliteal operations for atherosclerosis. Ann Surg 1973;178:232-246.

24 O'Rourke M: Mechanical principles in arterial disease. Hypertension 1995;26:2-9.

25 Boutouyrie P, et al: Opposing effects of ageing on distal and proximal large arteries in hypertensives. J Hypertens Suppl 1992; 10:S87-S91.

26 Lehoux S, Castier Y, Tedgui A: Molecular mechanisms of the vascular responses to haemodynamic forces. J Intern Med 2006; 259:381-392.

27 Haga JH, Li YS, Chien S: Molecular basis of the effects of mechanical stretch on vascular smooth muscle cells. J Biomech 2007;40: 947-960.

28 Hurley NE, et al: Modulating the functional contributions of c-Myc to the human endothelial cell cyclic strain response. J Vasc Res 2010;47:80-90.

29 Chang H, et al: Regulation of hypoxia-inducible factor-1alpha by cyclical mechanical stretch in rat vascular smooth muscle cells. Clin Sci (Lond) 2003;105:447-456.

30 Cheng JJ, et al: Cyclic strain enhances adhesion of monocytes to endothelial cells by increasing intercellular adhesion molecule-1 expression. Hypertension 1996;28:386-391.

- 31 Lim CS, et al: Prolonged mechanical stretch is associated with upregulation of hypoxiainducible factors and reduced contraction in rat inferior vena cava. J Vasc Surg 2011;53: 764-773.

- 32 de Waard V, et al: TR3 nuclear orphan receptor prevents cyclic stretch-induced proliferation of venous smooth muscle cells. Am J Pathol 2006;168:2027-2035.

33 Nichol JW, et al: Hemodynamics and axial strain additively increase matrix remodeling and MMP-9, but not MMP-2, expression in arteries engineered by directed remodeling. Tissue Eng Part A 2009;15:1281-1290.

34 Misra S, et al: The rat femoral arteriovenous fistula model: increased expression of matrix metalloproteinase- 2 and -9 at the venous stenosis. J Vasc Interv Radiol 2008;19:587-594.

- 35 Chung AW, et al: Pressure distention compared with pharmacologic relaxation in vein grafting upregulates matrix metalloproteinase-2 and -9. J Vasc Surg 2005;42:747-756.
36 Lehoux S, Tedgui A: Signal transduction of mechanical stresses in the vascular wall. Hypertension 1998;32:338-345.

- 37 Hill MA, et al: Therapeutic potential of pharmacologically targeting arteriolar myogenic tone. Trends Pharmacol Sci 2009;30:363374.

- 38 Hoffman BD, Grashoff C, Schwartz MA: Dynamic molecular processes mediate cellular mechanotransduction. Nature 2011;475: 316-323.

39 Numaguchi K, et al: Mechanotransduction of rat aortic vascular smooth muscle cells requires RhoA and intact actin filaments. Circ Res 1999;85:5-11.

$40 \mathrm{Li} \mathrm{C}$, et al: Ras/Rac-Dependent activation of p38 mitogen-activated protein kinases in smooth muscle cells stimulated by cyclic strain stress. Arterioscler Thromb Vasc Biol 2000;20:E1-E9.

41 Sotoudeh M, et al: Induction of apoptosis in vascular smooth muscle cells by mechanical stretch. Am J Physiol Heart Circ Physiol 2002;282:H1709-H1716.

42 Li Y, et al: Myogenic differentiation requires signalling through both phosphatidylinositol 3-kinase and p38 MAP kinase. Cell Signal 2000;12:751-757.

43 Birukov KG, et al: Increased pressure induces sustained protein kinase C-independent herbimycin A-sensitive activation of extracellular signal-related kinase $1 / 2$ in the rabbit aorta in organ culture. Circ Res 1997;81: 895-903.

44 Wung BS, et al: Modulation of Ras/Raf/extracellular signal-regulated kinase pathway by reactive oxygen species is involved in cyclic strain-induced early growth response-1 gene expression in endothelial cells. Circ Res 1999;84:804-812.

$45 \mathrm{Du}$ W, Mills I, Sumpio BE: Cyclic strain causes heterogeneous induction of transcription factors, AP-1, CRE binding protein and NF- $\kappa \mathrm{B}$, in endothelial cells: species and vascular bed diversity. J Biomech 1995;28: 1485-1491.

- 46 Zheng W, Christensen LP, Tomanek RJ: Stretch induces upregulation of key tyrosine kinase receptors in microvascular endothelial cells. Am J Physiol Heart Circ Physiol 2004;287:H2739-H2745.

47 Frye SR, et al: cDNA microarray analysis of endothelial cells subjected to cyclic mechanical strain: importance of motion control. Physiol Genomics 2005;21:124-130.

-48 Ives CL, Eskin SG, McIntire LV: Mechanical effects on endothelial cell morphology: in vitro assessment. In Vitro Cell Dev Biol 1986; 22:500-507.

49 Cheng WP, et al: The molecular regulation of GADD153 in apoptosis of cultured vascular smooth muscle cells by cyclic mechanical stretch. Cardiovasc Res 2008;77:551-559.

50 Stula M, et al: Influence of sustained mechanical stress on Egr-1 mRNA expression in cultured human endothelial cells. Mol Cell Biochem 2000;210:101-108.
51 Cornelissen J, Armstrong J, Holt CM: Mechanical stretch induces phosphorylation of p38-MAPK and apoptosis in human saphenous vein. Arterioscler Thromb Vasc Biol 2004;24:451-456.

52 Goldman J, Zhong L, Liu SQ: Degradation of alpha-actin filaments in venous smooth muscle cells in response to mechanical stretch. Am J Physiol Heart Circ Physiol 2003;284:H1839-H1847.

53 Mayr M, et al: Mechanical stress-induced DNA damage and rac-p38MAPK signal pathways mediate p53-dependent apoptosis in vascular smooth muscle cells. FASEB J 2002; 16:1423-1425.

54 Iwasaki H, et al: Mechanical stretch stimulates growth of vascular smooth muscle cells via epidermal growth factor receptor. Am J Physiol Heart Circ Physiol 2000;278:H521H529.

55 Mata-Greenwood E, et al: Cyclic stretch increases VEGF expression in pulmonary arterial smooth muscle cells via TGF-betal and reactive oxygen species: a requirement for NAD(P)H oxidase. Am J Physiol Lung Cell Mol Physiol 2005;289:L288-L289.

56 Milkiewicz M, et al: HIF-lalpha and HIF2alpha play a central role in stretch-induced but not shear-stress-induced angiogenesis in rat skeletal muscle. J Physiol 2007;583:753766.

57 Semenza GL: Regulation of oxygen homeostasis by hypoxia-inducible factor 1 . Physiology (Bethesda) 2009;24:97-106.

58 Kasivisvanathan V, et al: Hypoxia-inducible factor-1 in arterial disease: a putative therapeutic target. Curr Vasc Pharmacol 2011;9: 333-349.

59 Semenza GL: Vascular responses to hypoxia and ischemia. Arterioscler Thromb Vasc Biol 2010;30:648-652.

-60 Richard MN, et al: Mechanical stretching stimulates smooth muscle cell growth, nuclear protein import, and nuclear pore expression through mitogen-activated protein kinase activation. J Biol Chem 2007;282: 23081-23088

61 Feng Y, et al: Transcriptional profile of mechanically induced genes in human vascular smooth muscle cells. Circ Res 1999;85:11181123.

62 Albinsson S, Nordstrom I, Hellstrand P: Stretch of the vascular wall induces smooth muscle differentiation by promoting actin polymerization. J Biol Chem 2004;279: 34849-34855.

63 Rovner AS, Murphy RA, Owens GK: Expression of smooth muscle and nonmuscle myosin heavy chains in cultured vascular smooth muscle cells. J Biol Chem 1986;261:1474014745.

64 Stanley AG, et al: Mechanical strain-induced human vascular matrix synthesis: the role of angiotensin II. J Renin Angiotensin Aldosterone Syst 2000;1:32-35. 
65 Toda M, et al: Differential gene responses in endothelial cells exposed to a combination of shear stress and cyclic stretch. J Biotechnol 2008; 133:239-244.

66 Tsukurov OI, et al: The response of adult human saphenous vein endothelial cells to combined pressurized pulsatile flow and cyclic strain, in vitro. Ann Vasc Surg 2000;14: 260-267.

67 Cattaruzza M, et al: Stretch-induced endothelin B receptor-mediated apoptosis in vascular smooth muscle cells. FASEB J 2000;14: 991-998.

68 Casey PJ, et al: The effect of combined arterial hemodynamics on saphenous venous endothelial nitric oxide production. J Vasc Surg 2001;33:1199-1205.

69 Hishikawa K, Luscher TF: Pulsatile stretch stimulates superoxide production in human aortic endothelial cells. Circulation 1997;96: 3610-3616.

70 Iba T, et al: Stimulation of endothelial secretion of tissue-type plasminogen activator by repetitive stretch. J Surg Res 1991;50:457460.

71 Sumpio BE, Banes AJ: Prostacyclin synthetic activity in cultured aortic endothelial cells undergoing cyclic mechanical deformation. Surgery 1988;104:383-389.

72 Wung BS, et al: Cyclic strain-induced monocyte chemotactic protein-1 gene expression in endothelial cells involves reactive oxygen species activation of activator protein 1 . Circ Res 1997;81:1-7.

73 Wojtowicz A, et al: Zyxin mediation of stretch-induced gene expression in human endothelial cells. Circ Res 2010;107:898-902.

74 Okada M, et al: Cyclic stretch upregulates production of interleukin- 8 and monocyte chemotactic and activating factor/monocyte chemoattractant protein-1 in human endothelial cells. Arterioscler Thromb Vasc Biol 1998;18:894-901.

75 Kobayashi S, et al: Stretch-induced IL-6 secretion from endothelial cells requires NFkappaB activation. Biochem Biophys Res Commun 2003;308:306-312.

76 Zampetaki A, et al: Biomechanical stress induces IL-6 expression in smooth muscle cells via Ras/Rac1-p38 MAPK-NF-kappaB signaling pathways. Am J Physiol Heart Circ Physiol 2005;288:H2946-H2954.

77 Zhao H, et al: Cyclic stretch induces cyclooxygenase-2 gene expression in vascular endothelial cells via activation of nuclear factor kappa-beta. Biochem Biophys Res Commun 2009;389:599-601.

78 Huang G, et al: Mechanical strain induces expression of C-reactive protein in human blood vessels. J Pharmacol Exp Ther 2009; 330:206-211.

79 Lusic I, et al: Is C-reactive protein a better predictor of recurrent carotid disease following carotid endarterectomy than established risk factors for atherosclerosis? Vasa 2006; 35:221-225.
80 Verma S, Devaraj S, Jialal I: Is C-reactive protein an innocent bystander or proatherogenic culprit? C-reactive protein promotes atherothrombosis. Circulation 2006;113:21352150, discussion 2150.

81 Psychari SN, et al: Relation of elevated C-reactive protein and interleukin- 6 levels to left atrial size and duration of episodes in patients with atrial fibrillation. Am J Cardiol 2005;95:764-767.

82 Vainas T, et al: Serum C-reactive protein level is associated with abdominal aortic aneurysm size and may be produced by aneurysmal tissue. Circulation 2003;107:1103-1105.

83 Parolari A, et al: Systemic inflammation after on-pump and off-pump coronary bypass surgery: a one-month follow-up. Ann Thorac Surg 2007;84:823-828.

84 Prasad K: C-reactive protein increases oxygen radical generation by neutrophils. J Cardiovasc Pharmacol Ther 2004;9:203-209.

$>85$ Hobeika MJ, et al: Matrix metalloproteinases in peripheral vascular disease. J Vasc Surg 2007;45:849-857.

86 Visse R, Nagase H: Matrix metalloproteinases and tissue inhibitors of metalloproteinases: structure, function, and biochemistry. Circ Res 2003;92:827-839.

$>87$ Lim CS, et al: Matrix metalloproteinases in vascular disease - a potential therapeutic target? Curr Vasc Pharmacol 2010;8:75-85.

88 Raffetto JD, Khalil RA: Matrix metalloproteinases and their inhibitors in vascular remodeling and vascular disease. Biochem Pharmacol 2008;75:346-359.

89 Vartak DG, Gemeinhart RA: Matrix metalloproteases: underutilized targets for drug delivery. J Drug Target 2007;15:1-20.

90 Tamura K, et al: Molecular mechanism of fibronectin gene activation by cyclic stretch in vascular smooth muscle cells. J Biol Chem 2000;275:34619-34627.

-91 Wang BW, et al: Induction of matrix metalloproteinases-14 and -2 by cyclical mechanical stretch is mediated by tumor necrosis factor-alpha in cultured human umbilical vein endothelial cells. Cardiovasc Res 2003; 59:460-469.

92 Milkiewicz M, Haas TL: Effect of mechanical stretch on HIF-1\{alpha\} and MMP-2 expression in capillaries isolated from overloaded skeletal muscles: laser capture microdissection study. Am J Physiol Heart Circ Physiol 2005;289:H1315-H1320.

$\$ 93$ Grote K, et al: Mechanical stretch enhances mRNA expression and proenzyme release of matrix metalloproteinase-2 (MMP-2) via $\mathrm{NAD}(\mathrm{P}) \mathrm{H}$ oxidase-derived reactive oxygen species. Circ Res 2003;92:e80-e86.

94 Zhou D, et al: Differential MMP-2 activity of ligament cells under mechanical stretch injury: an in vitro study on human ACL and MCL fibroblasts. J Orthop Res 2005;23:949957.
95 Asanuma K, et al: Uniaxial strain upregulates matrix-degrading enzymes produced by human vascular smooth muscle cells. Am J Physiol Heart Circ Physiol 2003; 284:H1778-H1784.

$\checkmark 96$ Raffetto JD, et al: Prolonged increases in vein wall tension increase matrix metalloproteinases and decrease constriction in rat vena cava: potential implications in varicose veins. J Vasc Surg 2008;48:447-456.

$\$ 97$ Raffetto JD, Ross RL, Khalil RA: Matrix metalloproteinase 2 -induced venous dilation via hyperpolarization and activation of $\mathrm{K}+$ channels: relevance to varicose vein formation. J Vasc Surg 2007;45:373-380.

$\checkmark 98$ Lim CS, et al: Prolonged mechanical stretch is associated with upregulation of hypoxiainducible factors and reduced contraction in rat inferior vena cava. J Vasc Surg 2011; 53:764-773.

99 Ruddy JM, et al: Differential effect of wall tension on matrix metalloproteinase promoter activation in the thoracic aorta. J Surg Res 2010;160:333-339.

100 Pascarella L, et al: Mechanisms in experimental venous valve failure and their modification by Daflon $500 \mathrm{mg}$. Eur J Vasc Endovasc Surg 2008;35:102-110.

101 Cheng J, et al: The mechanical stress-activated serum-, glucocorticoid-regulated kinase 1 contributes to neointima formation in vein grafts. Circ Res 2010;107:1265-1274.

102 Pascarella L, Schmid-Schonbein GW, Bergan J: An animal model of venous hypertension: the role of inflammation in venous valve failure. J Vasc Surg 2005;41:303-311.

103 Takase S, et al: Hypertension-induced venous valve remodeling. J Vasc Surg 2004;39: 1329-1334.

104 Birukov KG: Cyclic stretch, reactive oxygen species, and vascular remodeling. Antioxid Redox Signal 2009;11:1651-1667.

105 Touyz RM, Schiffrin EL: Reactive oxygen species in vascular biology: implications in hypertension. Histochem Cell Biol 2004; 122:339-352.

106 Ali MH, Mungai PT, Schumacker PT: Stretch-induced phosphorylation of focal adhesion kinase in endothelial cells: role of mitochondrial oxidants. Am J Physiol Lung Cell Mol Physiol 2006;291:L38-L45.

107 Amma H, et al: Involvement of reactive oxygen species in cyclic stretch-induced NFkappaB activation in human fibroblast cells. Br J Pharmacol 2005; 145:364-373.

108 Cai H, Griendling KK, Harrison DG: The vascular $\mathrm{NAD}(\mathrm{P}) \mathrm{H}$ oxidases as therapeutic targets in cardiovascular diseases. Trends Pharmacol Sci 2003;24:471-478.

109 Ushio-Fukai M, et al: p38 Mitogen-activated protein kinase is a critical component of the redox-sensitive signaling pathways activated by angiotensin II. Role in vascular smooth muscle cell hypertrophy. J Biol Chem 1998;273:15022-15029. 
110 Lehoux S, et al: Pulsatile stretch-induced extracellular signal-regulated kinase $1 / 2$ activation in organ culture of rabbit aorta involves reactive oxygen species. Arterioscler Thromb Vasc Biol 2000;20:23662372.

$\checkmark 111$ Lemarie CA, et al: Transforming growth factor-alpha mediates nuclear factor kap$\mathrm{paB}$ activation in strained arteries. Circ Res 2006;99:434-441.

$\checkmark 112$ Chen Q, et al: Modulation of vascular smooth muscle cell alignment by cyclic strain is dependent on reactive oxygen species and P38 mitogen-activated protein kinase. J Vasc Surg 2003;37:660-668.

113 Laurikka JO, et al: Risk indicators for varicose veins in forty- to sixty-year-olds in the Tampere varicose vein study. World J Surg 2002;26:648-651.

-114 Somers P, Knaapen M: The histopathology of varicose vein disease. Angiology 2006; 57:546-555

115 Gillespie DL, et al: Varicose veins possess greater quantities of MMP-1 than normal veins and demonstrate regional variation in MMP-1 and MMP-13. J Surg Res 2002;106: 233-238.
116 Aunapuu M, Arend A: Histopathological changes and expression of adhesion molecules and laminin in varicose veins. Vasa 2005;34:170-175.

117 Sayer GL, Smith PD: Immunocytochemical characterisation of the inflammatory cell infiltrate of varicose veins. Eur J Vasc Endovasc Surg 2004;28:479-483

118 Saharay M, et al: Endothelial activation in patients with chronic venous disease. Eur J Vasc Endovasc Surg 1998;15:342-349.

119 Takase S, Bergan JJ, Schmid-Schonbein G: Expression of adhesion molecules and cytokines on saphenous veins in chronic venous insufficiency. Ann Vasc Surg 2000;14: 427-435.

120 Signorelli SS, et al: Venous stasis causes release of interleukin 1beta (IL-1beta), interleukin 6 (IL-6) and tumor necrosis factor alpha (TNFalpha) by monocyte-macrophage. Clin Hemorheol Microcirc 2000;22: 311-316.
121 Gohel MS, et al: The relationship between cytokine concentrations and wound healing in chronic venous ulceration. J Vasc Surg 2008;48:1272-1277.

122 Jacob MP, et al: Plasma matrix metalloproteinase- 9 as a marker of blood stasis in varicose veins. Circulation 2002;106:535-538.

123 Davies AH, et al: Pre-bypass morphological changes in vein grafts. Eur J Vasc Surg 1993; 7:642-764.

124 Wilson YG, et al: Vein quality influences neointimal hyperplasia in an organ culture model of human saphenous vein. Eur J Vasc Endovasc Surg 1997;13:557-562.

125 Pyle AL, et al: Biomechanical stress induces novel arterial intima-enriched genes: implications for vascular adaptation to stress. Cardiovasc Pathol 2010;19:e13-e20.

126 McMillan WD, et al: Size matters: the relationship between MMP-9 expression and aortic diameter. Circulation 1997;96:22282232.

127 Shalhoub J, et al: Innate immunity and monocyte-macrophage activation in atherosclerosis. J Inflamm (Lond) 2011;8:9.

128 Martinez R, et al: Mechanical buckling of veins under internal pressure. Ann Biomed Eng 2010;38:1345-1353. 